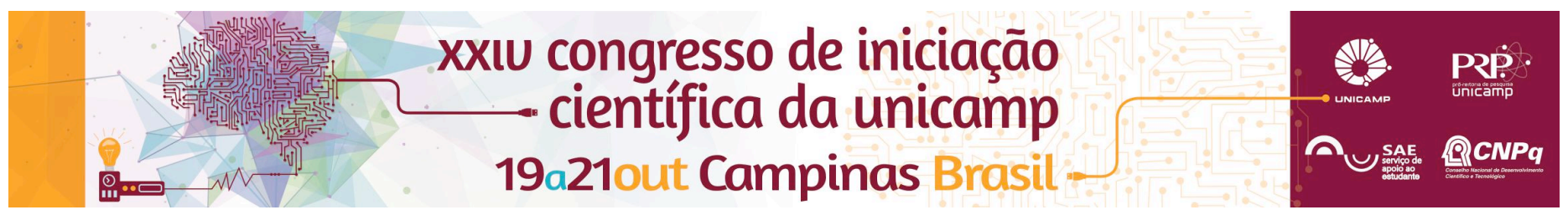

\title{
Construção de roteiro em espetáculos de dança: relações entre dramaturgia e pesquisa de movimento.
}

\author{
Mariana Baruco Machado Andraus, Milena Pereira dos Santos*.
}

\section{Resumo}

Este projeto prevê o entendimento de dramaturgia a partir de teóricos das áreas da dança e do teatro e a descrição da construção dramatúrgica do espetáculo "Se você se perdesse de si", cujo roteiro se construiu pela conexão entre movimento e sentidos, entre a inter-relação entre bailarinos e música, objetos cênicos, cenografia e estímulos multimídia. Participar da concepção e produção desta obra me possibilita descrever o processo e compreendê-lo à luz do referencial teórico proposto no projeto.

\section{Palavras-chave}

Dança, dramaturgia na dança, roteiro de espetáculo.

\section{Introdução}

O interesse em dramaturgia na dança surgiu a partir de experiências no teatro e no circo: a observação de como se dá a construção de espetáculos nessas duas linguagens me fez refletir sobre como esse mesmo processo acontece para/durante a criação de um espetáculo de dança. Paralelamente, fui convidada para participar do processo de criação do espetáculo proposto por Andreia Andrade, então aluna do $4^{\circ}$ ano do curso de Bacharelado em Dança da Unicamp, como seu trabalho de conclusão de curso, que gerou o espetáculo "Se você se perdesse de si", orientado pela Prof. Dra. Mariana B. M. Andraus, que trata cenicamente sobre a doença de Alzheimer.

São objetivos deste projeto a compreensão sobre o que é dramaturgia na dança a partir de teóricos das áreas da dança e do teatro como Gisela Dória, Daniela Gatti, Helena Katz, Sandra Corradini, Patrice Pavis e Eugenio Barba e a descrição detalhada do processo de criação do espetáculo "Se você se perdesse de si", que envolve como a dramaturgia desse espetáculo foi criada.

\section{Resultados e Discussão}

Para a pesquisa, que foi iniciada em fevereiro de 2016, foram realizados: a descrição dos caminhos e estratégias de criação do espetáculo "Se você se perdesse de si", ainda sem a preocupação com a análise do mesmo, e leituras e fichamentos das seguintes obras selecionadas para embasar o estudo sobre dramaturgia na dança: "Por uma dramaturgia que não seja uma liturgia da dança", de Helena Katz (2010); "Medeia: um experimento coreográfico", de Daniela Gatti (2005), "A poética de Sem Lugar: por uma teatralidade na dança", de Gisela Dória (2013) e "A Análise dos Espetáculos", de Patrice Pavis (2003).

A partir dos estudos realizados, pode-se afirmar que as três pensadoras da dança mencionadas concordam sobre o conceito de dramaturgia enquanto composição da cena da dança, na forma como os elementos são conectados para a construção da lógica do espetáculo, com o destaque do corpo e suas possibilidades, seus movimentos, uma vez que dança é corpo. Acrescenta-se ainda, segundo Dória, que a dramaturgia se finaliza na interlocução com o público, uma vez que é ele quem dialoga com a cena, construindo sentidos e atribuindo DOI: 10.19146/pibic-2016-51520 significados a esta. Ainda há mais escritos a serem estudados para complementar o conceito de dramaturgia. Outro conceito presente nos materiais estudados é o de teatralidade, aspecto presente no espetáculo "Se você se perdesse de si". Dória apresenta em seu livro o que significa tal conceito para Roland Barthes e para Patrice Pavis, e conclui que há um eixo da teatralidade que vai num sentido do real/cotidiano e outro do abstrato, que busca a reconstrução do espaço cênico, próximo da lógica do teatro pós-dramático, na criação de um ambiente onde as ações acontecem.

\section{Conclusões}

O projeto se encontra na fase inicial, mas já se pode perceber o caminho para a conceituação de dramaturgia na dança e como tal aspecto da criação cênica será explanado na análise do espetáculo "Se você se perdesse de si". A teatralidade, conceito e aspecto descoberto durante a pesquisa, é relevante, uma vez que é possível percebê-lo na obra que está sob análise, e será apontado na descrição do roteiro do espetáculo.

\section{Agradecimentos}

Fundação de Amparo à Pesquisa do Estado de São Paulo (FAPESP)

ANDRAUS, Mariana Baruco Machado. A poesia da luta: um olhar voltado para a gestualidade do estilo de gong fu louva-a-deus como estímulo para uma criação coreográfica. 2004. Dissertação (Mestrado em Artes). Universidade Estadual de Campinas, Campinas, 2004.

DÓRIA, Gisela. A Poética de Sem Lugar: Por uma Teatralidade na Dança. $1^{\text {a }}$ ed. São Paulo: Perspectiva, 2013.

GATTI, Daniela. Medeia: Um experimento coreográfico. 2005. Dissertação (Mestrado em Artes). Universidade Estadual de Campinas, Campinas, 2005.

KATZ, Helena. Por uma dramaturgia que não seja uma liturgia da dança. Sala preta. São Paulo. v. 10. p. 163-167. agosto/2010. http://www.revistas.usp.br/salapreta/issue/view/4702/showTo

PAVIS, Patrice. A Análise dos Espetáculos. São Paulo: Perspectiva, 2003. 